\title{
Pajés e feiticeiros
}

\section{CARMEN JUNQUEIRA}

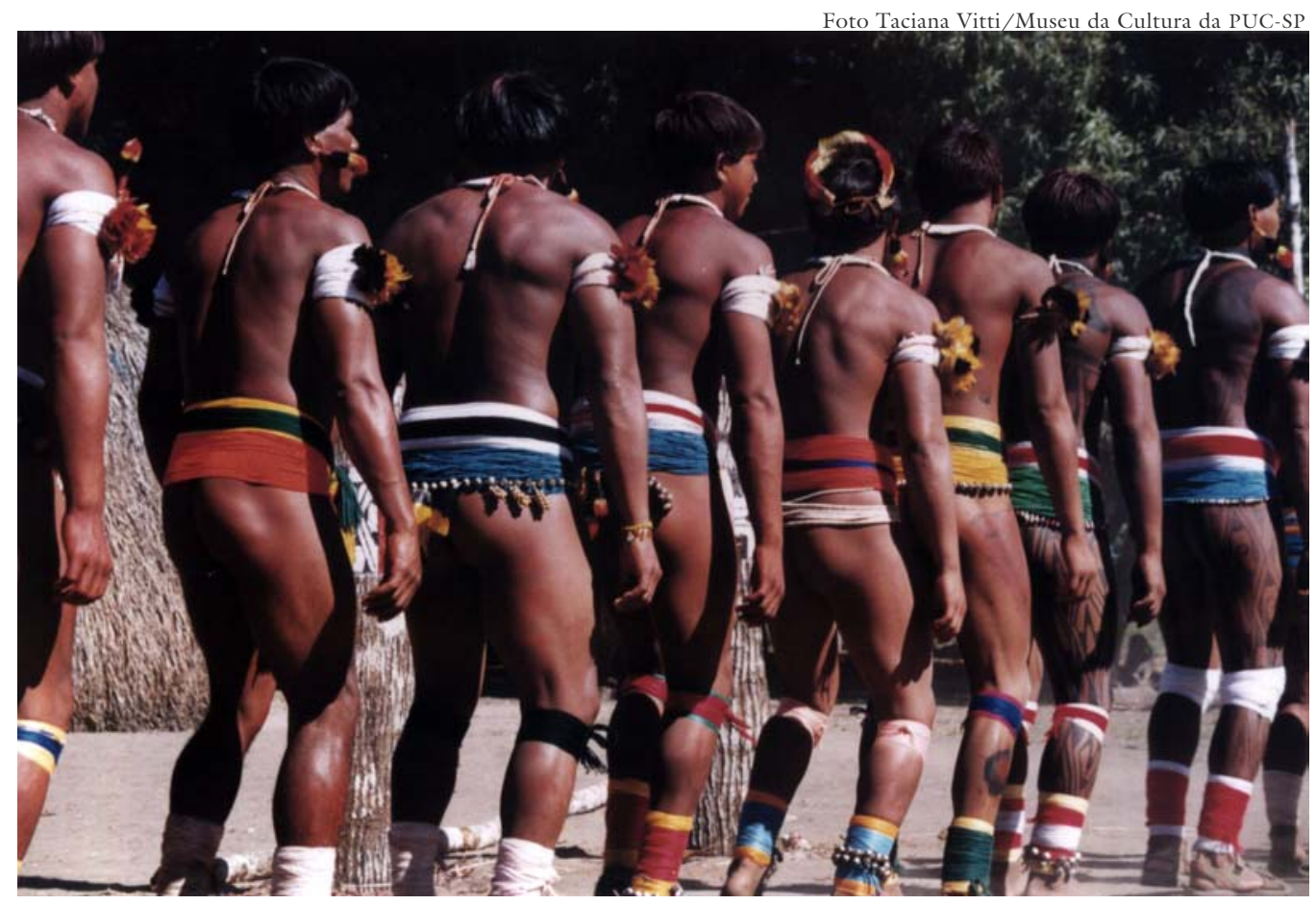

Kuarup: ritual em homenagem aos mortos na aldeia dos indios Kamaiurá.

$\mathrm{N}$

A sociedade Kamaiurá (Alto Rio Xingu), quando pensamos sobre os pajés, sua formação e seus rituais, podemos observar uma dinâmica que reúne a um mesmo tempo valores e comportamentos usualmente tidos como opostos. É no amplo campo das atividades políticas que aparecem seus principais mecanismos, em especial na disputa por maior prestígio e poder. Reside nessa arena, em que os desejos se igualam, uma fonte importante da desarmonia social (Girard, 1990). Os adversários tornam-se duplos uns dos outros e elegem a violência como arma principal para restabelecer a ordem ameaçada. Os dois atuam guiados pelo sagrado e nele encontram a força que necessitam para o combate.

A aldeia Kamaiurá, ao lado da lagoa de Ipavu, tem as casas distribuídas ao redor de um pátio circular. Cada casa tem um dono, o líder de um grupo de parentes, que organiza e coordena as atividades diárias. Ele não dá ordens, mas espera que todos sigam seu exemplo: roças grandes e bem cuidadas, e disposição para pescar. Ele se esforça para que sua casa seja farta, pacífica e assim consiga atrair outros parentes ou agregados, pois um elevado número de moradores aumenta seu prestígio junto aos demais chefes domiciliares. Desenvolve, ao lado 
disso, algumas habilidades especiais: embora seja firme na condução da liderança, procura ser simpático, tolerante, sereno, generoso. Contorna as disputas domésticas acomodando as partes, evitando intervenções que possam parecer autoritárias.

A generosidade é, sem dúvida, um fardo pesado para o chefe da casa. A missão de agradar os outros é um exercício de constante renúncia e significa trabalhar mais e abrir mão das próprias posses. Os mais fracos, de baixo prestígio, querem, pedem, com uma freqüência incômoda para os chefes, que assim se despojam de bens e se privam de um lazer mais ampliado. É curioso que fazem isso, senão com prazer, pelo menos com o sereno desprendimento que o cargo exige. A razão dessa virtude repousa numa necessidade de ordem prática, pois ao atender desejos e necessidades dos moradores, o chefe alimenta a dependência que a doação regular institui. Aquele que recebe se torna devedor e caso não retribua de modo adequado só lhe resta, conscientemente ou não, abrir mão da própria independência. Os benefícios contínuos que recebe, enfraquecem sua liberdade de escolha, pois sub-repticiamente a vontade do doador se impõe, como se fora sua própria vontade. O homem comum torna-se desse modo predisposto a acatar os conselhos do chefe, a seguir suas sugestões, sem que para isso seja necessário o uso de um poder explícito. A subordinação ocorre e é sustentada pela generosidade unilateral. Entretanto, esse é um tipo de poder que se desgasta no uso e exige contínuos investimentos para se renovar. O prestígio é posto à prova sem cessar, o que torna um martírio a vida do chefe, condenandoo ao eterno exercício da generosidade. E mais ainda, para não ter sua autoridade contestada e suas funções esvaziadas, ele não pode se descuidar das relações com os chefes das demais casas, seja renovando alianças ou neutralizando opositores.

Essa luta por prestígio não transparece no cotidiano da aldeia, que chama a atenção pelo ritmo compassado da vida e a serenidade das pessoas. O bom tom não recomenda manifestações exageradas: choros convulsivos, alegria esfuziante, raiva explosiva, amores tempestuosos. A dor, a felicidade, a ira e a paixão não devem ser externadas abertamente, sob pena de constranger o próximo. São regras seguidas de perto pela maioria, e na penumbra das longas casas ovais, o tom das vozes é baixo, os gestos discretos, o que combina com a elegância dos corpos, a beleza das pinturas e dos adornos.

Os Kamaiurá têm um modo peculiar de observar as coisas, reparando com vagar nos detalhes, como que buscando qualidades: cheiram, apalpam, testam o sabor. É um exame lento, cuidadoso, no qual os sentidos apurados são exigentes e não deixam que o tempo corra livre ordenando e definindo ritmos e limites. $\mathrm{O}$ tempo parece solidário com a vontade de conhecer. E possível, também, que esse uso profundo dos sentidos estimule a criatividade mítica, ampliando os registros da imaginação, permitindo enxergar uma riqueza de relações, semelhanças e oposições escondidas na aparente insignificância das coisas materiais mais corriqueiras. 
Criaram assim um mundo invisível povoado de forças e poderes que acompanham de perto as pessoas, interferindo de modo aberto em suas vidas. São os mitos uma boa pista para encontrar um dos fios dessa complexa meada. Pode-se dizer que, de modo geral, os mitos carregam pelo menos duas preocupações constantes, que podem ser captadas tanto através dos acontecimentos narrados como dos atores envolvidos. Uma dessas preocupações diz respeito ao tipo de comportamento que deve servir de modelo para uma vida social tranqüila. O recurso geralmente usado é narrar o que é tido como errado, condenável, para que o ouvinte por si mesmo chegue à conclusão esperada. Não há narrativas com um fecho moral, mas apenas o relato de uma sucessão de eventos que deixa claro a presença da recompensa ou punição. Os temas mais recorrentes são a falta de lealdade e a premeditação maldosa, a avareza, o ciúme exagerado, o incesto. $\mathrm{O}$ ciúme, por exemplo, embora aceito como um dos ingredientes do amor, se excessivo acarreta a intolerância e dificulta a convivência. Para mostrar isso, o mito conta o caso da mulher que não aceita a presença da segunda esposa do marido, e que acaba abandonada quando são descobertas suas artimanhas. Ou é o caso do homem que, cego de ciúme, procura uma forma de matar o irmão e rival, e que finalmente perde a mulher e a vida. Há ainda relatos em que a mulher se volta contra a nora, tecendo intrigas, forjando mentiras; se não perde o amor filial é perseguida e mesmo morta pelos netos. Destino semelhante têm o incestuoso, o desleal, o dissimulado, o avaro (Junqueira, 1997, pp. 28-32).

Outra inquietação que povoa muitos mitos tem natureza mais transcendental, afastando-se das pequenas questões do dia-a-dia. Trata-se do difícil problema de explicar o fenômeno da vida, como ela surgiu, qual sua essência. Como o Kamaiurá não consegue deslindar esse misterioso princípio, é levado a buscar a figura de um criador, o que resulta numa forma de contornar a questão e satisfazer a curiosidade.

Vida é impulso, movimento, enquanto a imobilidade é prenúncio da morte. Dessa perspectiva, praticamente todo o universo é vivo, em quase tudo se pode notar algum tipo de movimento seja nos animais, plantas, águas, ventos, astros. Diversos desdobramentos dessa reflexão podem ser encontrados nos mitos que falam da instauração dos grupos sociais, das diferenças entre povos, das características de espécies animais etc.

Foi Mavutsinin quem esculpiu em madeira os primeiros homens (Junqueira, 1979, p. 20); em outra versão, ele que vivia sozinho, sem mulher, sem parente, resolveu se casar com uma concha. Quando o filho nasceu ele o carregou consigo, largando a mulher que voltou para as águas da lagoa. "Nós, dizem os índios, somos netos do filho de Mavutsinin” (Villas Bôas, 1970, p. 55).

Quando a vida foi criada, todos os seres se comunicavam numa mesma língua, o que facilitava a união entre espécies diferentes. E, mais ainda, por trás da aparência diversa residia uma semelhança niveladora: todos eram uma concretização do fenômeno da vida e, mais, eram mortais e possuíam uma alma. O 
fundamento que os animava era o mesmo e a diferença de aspecto pouco significava, daí serem comuns os casamentos de homens e mulheres com onça, jabuti, gavião, arara, saúva, jacaré, abelha.

Um dia, quando as duas mulheres de Waytsó ìt foram à roça encontraram no caminho um rapaz bonito, todo enfeitado com colar, brinco, cinto. Quem será esse?, perguntaram entre si. Criando coragem, falaram com o desconhecido, indagando quem era, o que fazia ali. No que ele respondeu: sou o jacaré. Vim aqui para namorar vocês. Depois de muitos agrados ele foi com uma delas até o mato onde namoraram. Logo em seguida, levou a outra. Satisfeitos, se despediram. As moças o acompanharam até à beira da lagoa, onde ele se transformou em jacaré e mergulhou nas águas, prometendo voltar no dia seguinte...

Para os Kamaiurá não há necessidade de justificar o namoro entre mulher e jacaré, ficando evidente que se trata do encontro de dois seres constituídos de igual fundamento. Em outra versão do mesmo mito, os índios explicitam a igualdade básica dizendo: "elas chegaram; então ele (o jacaré) tirou a pele dele e ficou igual a gente, muito bonito..." (Samain, 1991, p. 171).

Mas os animais são eleitos parceiros do homem não apenas porque compartilham substâncias comuns, mas também por serem, alguns deles, dotados de poder para curar e conceder favores. Pássaros, peixes, veados, entre outros, são donos de conhecimentos superiores. A existência do próprio pajé, enquanto especialista em cura, deve-se à ajuda que os bichos lhe concedem, ensinando-lhe como fumar, como lidar com as doenças e curar. No mais das vezes, sem a ajuda do espírito do animal protetor, é impossível ao pajé acabar com a doença, auxiliar um parto complicado, localizar pessoas extraviadas na mata etc. E o pajé experiente sabe que para contar com tão valiosa ajuda deve obedecer rigorosamente às instruções que recebe e respeitar as interdições impostas, por mais difíceis que possam parecer. Qualquer infração pode acarretar a morte do aprendiz, como ensinam muitos relatos.

Os espíritos animais são ainda dotados de personalidade e temperamento variáveis. Há que saber como chamá-los e o momento propício para o pedido de ajuda. O pajé aprende que para obter favores deve se abster de certos alimentos, consumir pimenta, afastar-se das mulheres. Para o Kamaiurá, não há nada mais perigoso do que iniciar os trabalhos de pajelança com "cheiro". Referem-se eles ao cheiro de quem teve relação sexual com mulher, não importando quantos banhos tomou, pois o "cheiro" se agarra à pessoa por vários dias. O "cheiro" quebra qualquer magia, inviabiliza o contato com os espíritos guardiões e pode causar danos irreparáveis.

Essas construções permitem ver, de modo preliminar, como se elaborou o sentido da existência, através do apelo à origem e substância comuns, e que resultou num forte laço entre o Homem e a Natureza. A rigor, nem seria correto tratar Homem e Natureza como coisas separadas, uma vez que os próprios índios 
não estabelecem qualquer ruptura entre eles. Um estudo mais aprofundado da mitologia Kamaiurá poderia revelar uma união ainda mais ampla entre homens, espécies vivas, astros e forças naturais. Ao nomear os fenômenos da natureza, concedendo-lhes características humanas, os índios estão destacando a unidade do cosmos. A partir daí, os seres tanto visíveis como invisíveis dotam o Homem de conhecimentos, sentimentos e poderes. A natureza é una e abriga criações enriquecidas que contam com espírito, como os seres humanos e os encantados, e outras que exibem apenas materialidade, como certos animais, plantas, e a matéria inorgânica de modo geral. Esse intrigante imaginário é uma das vias de acesso ao universo Kamaiurá, que só pode ser conhecido pela mente, e que chega até nós pelos mitos e relatos esotéricos.

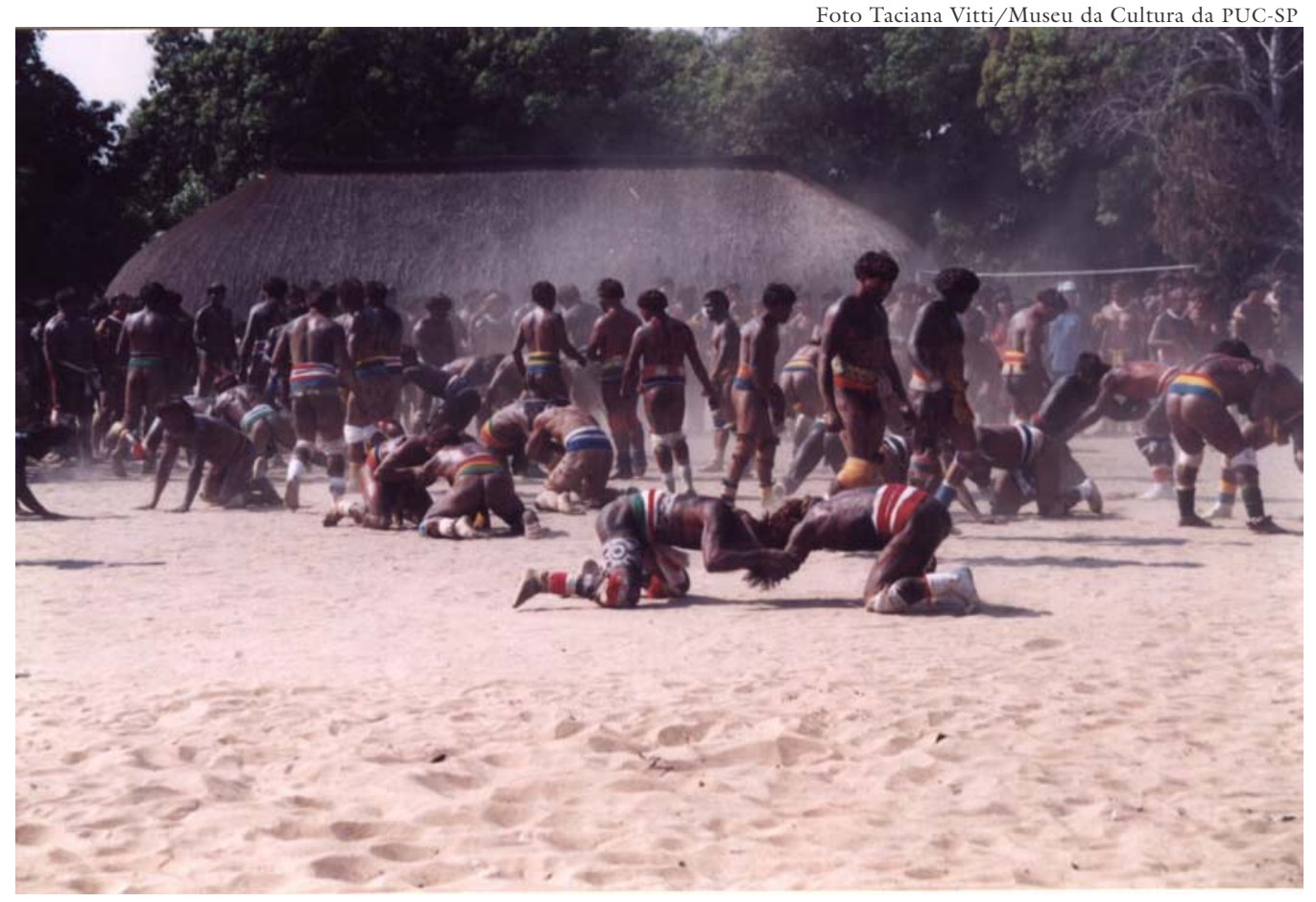

Kuarup: luta buka-buka.

Esse sentido de existência humana, que transcorre num universo cheio de magia e onde espírito e matéria se interligam, tornou-se ainda mais rico por força da curiosidade e da imprudência do Sol (Kwat) e da Lua (Yaì), na época em que ainda partilhavam da vida na aldeia dos homens.

Intrigados com o comentário feminino de que os homens não tinham ciúme, os gêmeos buscaram um modo de se apoderar do misterioso sentimento. Depois de muito procurar, finalmente acharam a casa do passarinho, seu dono, sem suspeitar que já tinham absorvido pelo caminho boa dose do ciúme que emanava da própria atmosfera encantada do local. Pediram então a ele que lhes cedesse um pouco de ciúme para levar à aldeia. Insistiram, mesmo depois de alertados que já tinham se impregnado dele pelo caminho. O passarinho para 
não contrariá-los deu-lhes mais um punhado de ciúme. Voltaram para a casa já se estapeando, brigando, repletos de ciúme que estavam. Passaram a bater nas mulheres e por qualquer motivo ficavam perdidos de ciúme. Era tanto o ciúme que Kwat não resistiu e caiu doente. Mais do que depressa, Yaì correu em busca de socorro, implorando que curassem o pobre Kwat. Vários passarinhos seguiram para lá e, levando consigo seus mamáe, mostraram ao mundo como se cura: o primeiro payé a se aproximar da rede foi o bem-te-vi que, se transformando em sua própria essência, pousou a mão sobre o peito de Kwat e de lá tirou um tanto do ciúme que o afligia. E assim fez o jacu e, um a um, todos os passarinhos-paye, cada qual retirando do peito enfermo um punhado do mal. Ninguém sabe se por sabedoria, ou castigo, o último deles deixou um restinho de ciúme lá dentro. Daí em diante, e até nossos dias, todos carregam o ciúme no peito e com ele temperam seus amores.

A aventura dos dois irmãos serviu para mostrar que é possível contar com a ajuda de aves, peixes e outros bichos e plantas que em sua essência são seres espirituais, têm mama'e. Mas nem todos os mama'e são de boa índole e há os que enviam doenças e tormentos às pessoas. Os mama'e bons habitam objetos cerimoniais, como as flautas jakui e o zunidor, outros pertencem às águas, ao tabaco, à mandioca, ao pequi, ou ainda à gaivota, beija-flor, bem-te-vi, o passarinho kapaié, vários peixes, formiga saúva, jacaré, entre outros. Alguns dos bichos que têm mamáe ruím são: macaco guariba, porco do mato, veado de porte pequeno, peixe cará (krapitã), peixe etowi, peixe puïrake e o beija-flor preto com lista branca.

O ser humano é uma exceção notável, não tem mama'e, mas apenas sombra, alma, objeto da cobiça dos mamáe e ocasionalmente por eles furtada. Essa carência torna o homem frágil e desamparado, e para garantir vida melhor ele deve observar as muitas interdições que a tradição aponta. Essa carência é compensada pela ajuda dos próprios mamáe. Não se sabe exatamente como eles fazem tal escolha, elegendo alguns poucos para se tornarem pajés. Uma visão, um sonho, uma doença, podem ser sinal de uma revelação que está por ocorrer. A pessoa que recebe o aviso para se iniciar na pajelança deve observar longo período de abstinência sexual, sob pena de ter seus futuros poderes afetados ou mesmo contrair doença fatal. Essa restrição é mais severa que a alimentar, também rígida, e de certa forma limita o aparecimento de pajés.

Purificado o corpo, o mamáe virá num sonho para instruir o eleito nos procedimentos da pajelança. A cada aparição, novos conhecimentos esotéricos são transferidos até que se complete a formação. O trabalho do pajé abrange um vasto campo do mundo espiritual; ele não só realiza curas como previne a comunidade de males, localiza objetos furtados, identifica feiticeiros etc. Parte das sessões pode ser pública, contando com a ajuda dos pajés da aldeia ou mesmo de fora, dependendo da gravidade do caso. O tabaco é ingrediente básico e consumido largamente durante os rituais que podem durar horas ou mesmo dias. 
O mundo dos espíritos, dos mama'e, ajuda o pajé a controlar as forças que ameaçam o corpo e a alma e que se manifestam como poluição e desordem. Mas os próprios espíritos têm poder desigual, o que dota os pajés de poderes também desiguais. A inevitável competição entre pajés estimula a procura de novos conhecimentos, ervas, alimentos, fórmulas que possam enriquecer a prática xamânica e trazer maior prestígio social. São particularmente valorizados os remédios em forma de colírio, que estimulam visões mais potentes, sonhos mais freqüentes. As experiências são feitas longe de todos e cada descoberta é guardada em profundo segredo.

Em meio a rivalidades no terreno espiritual, o poder de alguns pode ser colocado sob suspeita, sob a alegação de terem infringido regras durante a iniciação ou de estarem poluídos por relações com mulher. Na hierarquia de poderes, os pajés escolhidos pelos mamáe e que receberam ensinamentos diretamente deles durante sonhos ou transes, ocupam posição superior, quando comparados aos que foram iniciados por outro pajé, de quem receberam instruções e treinamento.

Dois eventos bastante comentados na aldeia exibem a excelência dos pajés Kamaiurá. Conta-se que um Kalapalo preparava-se para ir pescar quando os dois filhos do dono da casa pediram para ir também. O pai autorizou as duas crianças a acompanharem o pescador. Ao chegarem ao local, o pescador ficou na canoa aguardando os peixes, enquanto elas foram pegar caranguejo na praia. Terminada a pescaria, o homem viu que tanto o menino quanto a menina haviam desaparecido. Procurou-os por todos os lados, chamou, gritou seus nomes sem resultado. Voltou apressado para a aldeia, onde relatou ao pai o desaparecimento. Para tornar a busca mais acurada, um grupo de homens seguiu para o local. Entraram fundo no mato, vasculhando os arredores sem êxito. Os pais, desolados, contrataram vários pajés da própria aldeia e de outras: um deles afirmou que as crianças estavam no fundo d'água; outro, que haviam sido comidas por uma onça; outro ainda que elas estavam mortas na mata. O tempo foi passando, quando decidiram pedir os serviços de um grande pajé Kamaiurá. Seguiram para a aldeia Kalapalo o pajé e dois auxiliares, igualmente famosos. Lá chegando, receberam cigarros do pajé local que discretamente aceitaram e guardaram, mesmo porque foram advertidos pelo principal que deveriam enrolar seus próprios cigarros. Estavam presentes na aldeia pajés locais e de fora, todos querendo acompanhar os trabalhos. A sessão se prolongou até que veio o transe e o grande pajé recebeu seu mamaé que confirmou que as crianças estavam vivas na mata, na companhia de um veado. Nas horas seguintes, depois de muito tabaco e chamamentos, o veado veio trazendo as crianças. O grande pajé pediu silêncio, mandando que se retirassem dali os que tivessem "cheiro". Em pouco tempo a menina entrou na aldeia, vindo direto para os braços do seu salvador. Apareceu em seguida o menino. A aldeia vibrou de alegria. As duas crianças estavam sadias e traziam um “colar" de carrapatos em volta do pescoço e um círculo também de carrapatos ao 
redor dos olhos. A mãe quis tirá-los, mas elas não deixaram, dizendo que o enfeite tinha sido dado a elas pelo veado. O pajé mandou então que esquentassem água para banhá-las e com isso as livrar dos carrapatos. As crianças contaram então que, enquanto brincavam com caranguejos, apareceu um veado que perguntou se queriam comer frutinhas, levando-as até uma árvore carregada. Seguiram depois de árvore em árvore, mata adentro, deliciando-se com frutas muito especiais. Passaram assim dias e dias, até que o veado resolveu trazê-las de volta. O trabalho dos pajés foi bem recompensado: o principal deles recebeu três colares e seus dois auxiliares, dois cada um.

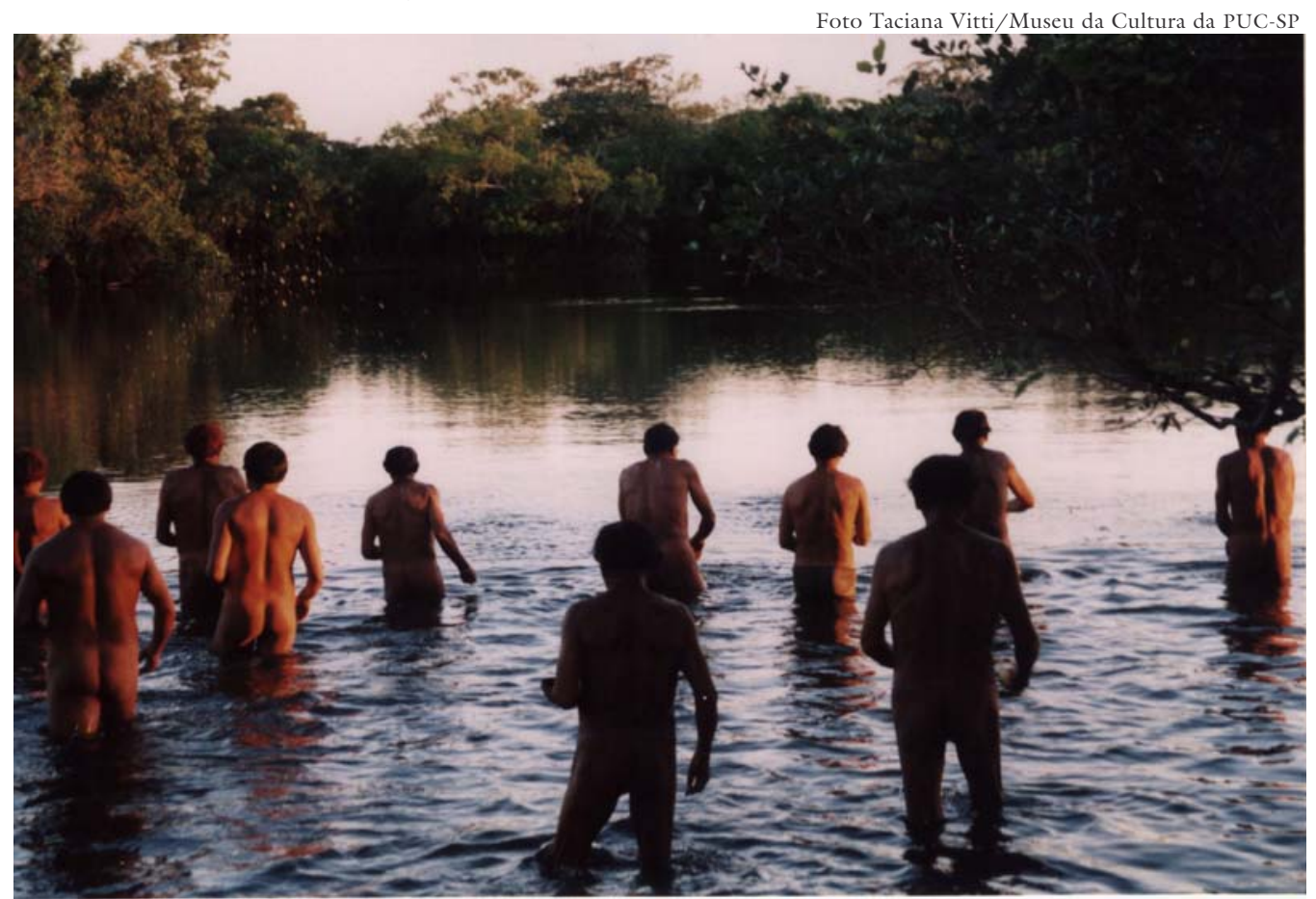

Dar de comer ao espírito da arraia para que ela não machuque ninguém durante a pescaria.

Numa outra ocasião, uma mulher Matipu veio até à aldeia Kamaiurá em busca dos serviços do grande pajé. Seu irmão havia se embrenhado no mato e sumido, e os pajés até então consultados não tinham obtido êxito. Conta-se na aldeia que inicialmente foi feito um primeiro trabalho na rede da vítima, que foi enrolada e em seguida envolvida pelas baforadas do cigarro do pajé. A fumaça entrou na rede, saiu em forma de uma bola que aos poucos se transformou na figura de um homem que apontava para o local onde o desaparecido se achava, voltando em seguida à forma de bola, depois em um fio de fumaça, para finalmente retornar à rede. Se, em lugar disso, não houvesse a formação da bola e a fumaça se dispersasse pelo ambiente, seria sinal de que o homem estava morto. Em seguida e durante muitos dias, vários pajés se reuniram em duas longas sessões diárias, cantando, fumando e fazendo uma corrente de força para trazer o homem de volta. Dizia-se que ele não estava perdido, mas enfeitiçado e corren- 
do risco de virar bicho. Felizmente, os mamáe invocados acabaram por atender o pedido e o homem voltou vivo, embora sujo e faminto. A ocasião forneceu um bom pretexto para confirmar a ineficiência dos pajés de outras aldeias.

Os sonhos ocupam lugar de destaque no mundo alto-xinguano, pois por meio deles os pajés conversam com os mama'e. É o veículo privilegiado de comunicação. Mas o mundo dos sonhos é complexo e não se reduz a isso. Há, por exemplo, dois tipos de sonho: um que envolve a presença de mamáe e que as pessoas comuns não sabem identificar, pensando tratar-se apenas de sonhos com animais, índios e símbolos. O outro tipo é aquele que reflete acontecimentos que nos preocupam ou eventos marcantes. O pajé consegue decifrar ambos. No sonho commamáe, os espíritos vêm dar conselhos, indicar soluções, fazer advertências ou apenas conversar. De modo geral, pesadelos ou sonhos muito tristes indicam que alguma coisa ruim está para acontecer e o melhor que se faz é não sair de casa. Sonhos de voar, fazer visitas, ter encontros inesperados ocorrem quando a alma fica passeando fora do corpo, pois quando dormimos ela fica livre para fazer o que quer. Desse modo, tais sonhos são reais, no sentido de que a alma realiza de fato as viagens, visitas, deslocamentos. Sonhar com pessoas que já morreram significa que temos saudades delas e que, eventualmente, elas têm saudade de nós. São encontros que as respectivas almas têm e que tendem a ser mais freqüentes no período mais próximo da morte da pessoa, ou quando algum evento nos faz lembrar dela. Nosso pensamento leva a alma ao encontro para amenizar a ausência e a dor.

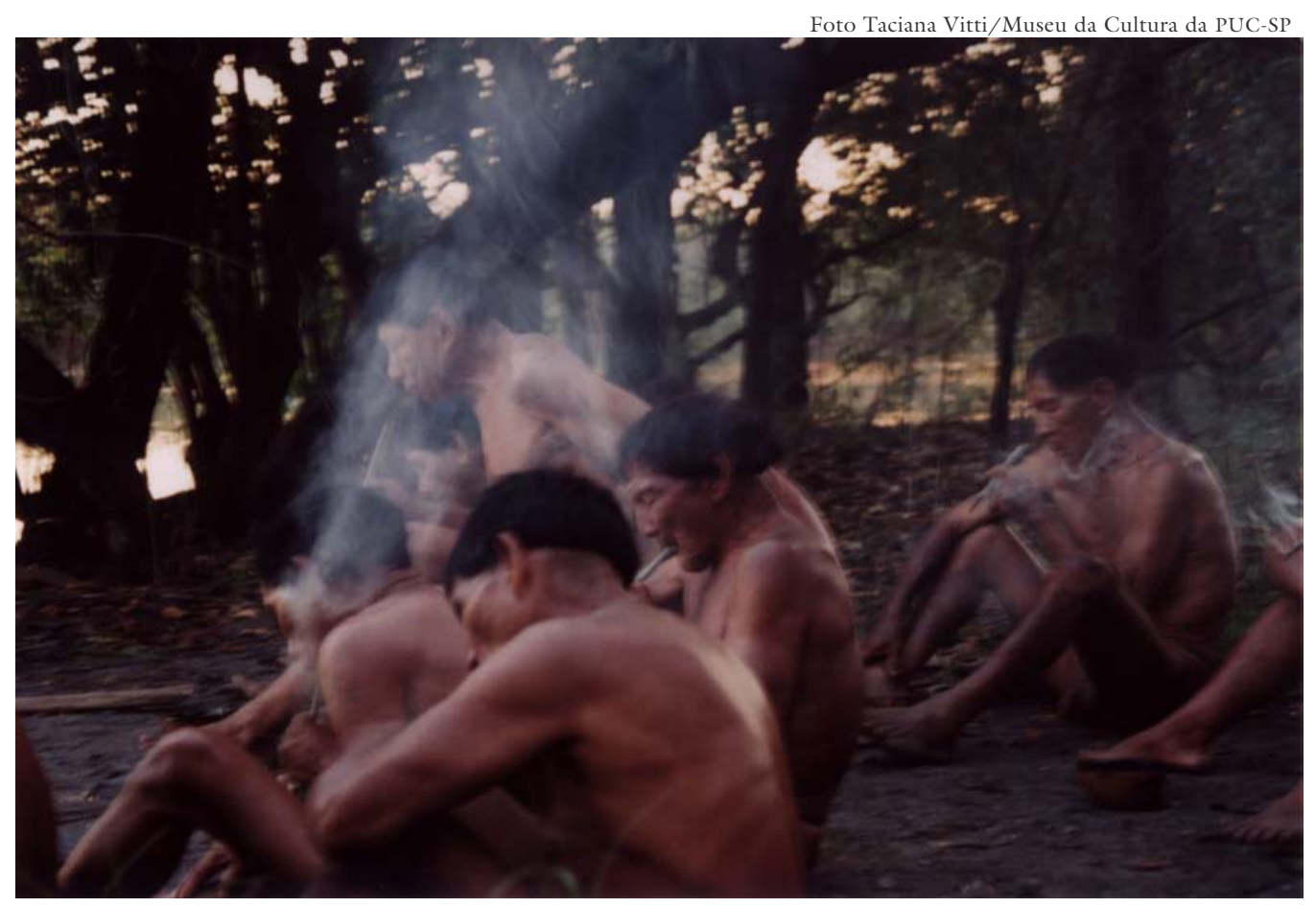

Pajés Kamaiurá se reúnem para fumar durante ritual. 
Todas as pessoas sonham, assim como os animais, externando suas preocupações, temores, alegrias e tudo mais que compõe a vida psíquica. Plantas, água e mama'e não sonham. Somente as pessoas iniciadas na pajelança são capazes de deslindar o enigma do sonho e utilizá-lo em benefício de clientes ou da vida social. O transe, provocado pelo consumo ritual do tabaco, é de certa forma similar ao sonho e permite contato com o mamáe, mesmo em vigília. É um outro modo de abrir a mente para absorver mensagens e instruções e que pode contar com a ajuda de outros pajés, o que significa aumentar o poder da evocação. Nessas sessões, sentados em círculo, cada um aspira boa quantidade de fumaça numa só baforada de um cigarro que é passado de mão em mão. De quando em quando, o pajé que lidera os trabalhos inicia o chamado do seu mama'e, no que é acompanhado pelos demais, que repetem o nome desse mesmo mama'e. Muitas horas se passam até que exaustos e intoxicados pela fumaça eles encerram a cerimônia, recolhendo-se às redes. Dependendo da gravidade do caso, essas sessões se repetem por vários dias, até que o mamáe venha ao encontro do pajé, no transe ou num sonho.

Os Kamaiurá cuidam do corpo com invulgar atenção e usam ervas, raízes, defumadores, escarificações, vomitórios e uma série grande de procedimentos para assegurar a saúde. Quando advém a doença, as primeiras providências são domésticas, com o uso dos remédios tradicionais. Persistindo o mal, vai-se ao pajé, pois desconfia-se de algo espiritual. A maioria das doenças tem origem na ação de espíritos, transgressões rituais e violações involuntárias de tabus. A freqüência ao pajé é grande e só não é maior porque seus serviços devem ser pagos.

Mas a grande ameaça que ronda a aldeia vem do feiticeiro, figura misteriosa, de identidade dissimulada. Responsável por desgraças continuadas e mortes inexplicáveis, ele é temido, mas se chega a ser identificado, nada mais lhe resta do que se refugiar em outra aldeia para evitar a vingança dos parentes das vítimas.

Sua magia é adquirida não com a intervenção de espíritos tutelares, mas através de uma disciplina do corpo e da vontade que conduz à domesticação da dor. $\mathrm{O}$ feiticeiro entretém, desse modo, um diálogo soturno com animais peçonhentos. Oferece a mão para receber picadas venenosas da formiga tocandira, Arranha-se com o escarificador e passa pimenta sobre os ferimentos, para aumentar a dor. Coloca taturana sob os braços, nas axilas, deixando-se queimar. Esfola-se com esporão da arraia e com dente de jararaca. Quando a dor beira senão o prazer mas ao menos a satisfação, operou-se o milagre: um poder humano, mas tão ou mais potente que as forças da natureza, ilumina o oficiante. São rituais que envolvem dor e veneno, mas que para ele significam fortalecimento e potência, tornando-o pronto para eliminar adversários com a mesma facilidade que o mama'e captura almas ou lança castigos. Mas ele supera os mama'e em poder, pois não há nada conhecido que possa anular a ação de um feitiço forjado para matar, dizem os grandes pajés. O feiticeiro é o soberano da morte e lançado $o$ feitiço não há nada a fazer. 
Diante de tão grave ameaça, a comunidade se mantém atenta aos acontecimentos que possam ser relacionados a feitiços, como doenças repentinas, mortes inexplicáveis, desgraças continuadas. Este é um assunto espinhoso, que quase ninguém gosta de aprofundar ou mesmo comentar, e as poucas respostas são quase sempre evasivas, vagas: "Hoje em dia não existe mais feiticeiro, antigamente, sim, mas foram todos mortos". "Feiticeiro existe entre os Kuikuro, os Aweti, aqui não". É preciso paciência e sorte para ter acesso ao mistério.

O feitiço tem uma longa história que se inicia no tempo“"dos antigos", quando os Kamaiurá estavam no Wawitsá (região onde hoje moram os Ikpeng): uma mulher e seus dois filhos saíram para pescar, quando viram muitos peixinhos num buraco. "Olha quanto akari (cascudo)! Pegue aquele, mamãe." Assim que pegou o peixe, ela morreu. Os rapazes choraram muito e voltaram à aldeia para o enterro. Depois que passaram pelo ritual do banho para acabar a tristeza, contaram ao tio Uaimiku o que havia acontecido: "Pensamos que era peixe, mas era um pedaço de pau e quando ela o pegou levou o choque mortal!". No dia seguinte voltaram ao local com o tio, que examinou bem o pau preto dentro da água e concluiu: "Acho que isso é feitiço (moã)", disse ele pensativo. Mais tarde ele retornou ao local, trazendo muita pimenta para mastigar e quando se sentiu preparado entrou na água e tocou o pau. Levou choque, mas pôde agüentar porque havia comido muita pimenta e com jeito conseguiu tirar o pau do buraco, levando-o para a aldeia.

No dia seguinte, quando foi se banhar ele viu uma moça e jogou um pedacinho do pau nela. Depois do banho a moça foi para a roça, mas não conseguiu trabalhar devido à febre que tomou conta do seu corpo. Poucas horas depois ela morria. A rapidez da morte espantou toda a aldeia, pois ninguém imaginava a existência do feitiço. Uiamiku quis testar uma vez mais e jogou outro pedacinho do pau num rapaz que estava em reclusão. Em algumas horas ele também morria. O medo tomou conta de todos que começaram a buscar uma explicação. Um deles, um homem esperto e observador, pôs-se a pensar e acabou por fazer a ligação entre as três mortes. Convidou então um dos sobrinhos de Uiamiku para ir pescar e a certa altura lhe perguntou: "É verdade que seu tio pegou o feitiço que matou sua mãe?” "Sim, ele pegou". "Ah! é por isso que nós estamos morrendo. Depois da sua mãe, morreu a mocinha, depois o rapaz que estava em reclusão, depois outro e mais outro, e ainda outro... Nós vamos matá-lo".

O tio, sabendo do perigo que corria, fugiu para a aldeia de Arupati. Mas Arupati, que não gostava ele, descobriu que ele andava jogando feitiço nas pessoas e decidiu que era melhor matá-lo. Mas novamente Uiamiku é alertado por um amigo: "Arupati vai dar uma festa e matar você". "Se ele me matar - disse ele ao amigo - você joga isto dentro da comida dele".

A festa começou animada, com todos dançando e se divertindo. Até que, de repente, um homem veio por trás de Uiamiku, flechando-o. O amigo depois de se banhar foi para perto do fogo onde Arupati cozinhava, fingindo querer se 
esquentar. Assim que pode, jogou o feitiço dentro da panela. Quando a festa acabou, foram todos comer com Arupati. Um a um morreram. Apenas o amigo de Uiamiku e sua família, que haviam deixado a festa e ido para a roça, viveram para relatar a história e ensinar as gerações seguintes a usar o feitiço. Desde então, o feitiço passa de pai para filho, deste para o neto, chegando assim até os dias atuais.

É preciso não confundir o feitiço (moã) com outras técnicas mágicas em uso na aldeia. Há uma substância vermelha como o urucum, muito usada para resolver amores não correspondidos, é o kurité. Basta fazer dois bonequinhos de palha de buriti, amarrar um ao outro, tingir com kurité e colocá-los na rede da pessoa desejada, que em pouco tempo o amor é correspondido. Homens e mulheres têm acesso ao kurité, que assim transformam desprezo e indiferença em amor e felicidade. Quando não se tem kurité, o encantamento pode ser feito através de rezas. Há a reza do tucano, a do papagaio. Do mesmo modo que tucano e papagaio domesticados não saem de perto do dono, suas rezas atuam no mesmo sentido. Basta repetir o sortilégio perto da pessoa desejada. "É por isso que há tanto homem velho, magro e feio casado com moça bonita", cochicham.

Frente ao feitiço, a situação é outra. Ao lado do medo, os Kamaiurá nutrem respeito e ódio pelos feiticeiros, sempre incógnitos e prontos a não revelar sua verdadeira identidade. Entretanto, à medida que as suspeitas vão se acumulando, aumenta a possibilidade de identificá-lo. Comenta-se que ele próprio ao pressentir que foi descoberto, enfeita-se como para uma grande festa e vibrante de orgulho aguarda a chegada da morte. Na década de 1950, a comunidade foi abalada pela morte de um grande líder atribuída à feitiçaria. Na aldeia usaram de todos os recursos para identificar o autor, mas coube a um especialista da tribo vizinha Aweti confirmar as suspeitas. Os Mehinako se ofereceram para matar o feiticeiro e foram ao seu encalço. Encontraram-no coberto de atavios, dançando no meio do mato, sem esboçar qualquer preocupação com a chegada dos homens que vinham exterminá-lo. Como pagamento, os Mehinako receberam um espelho grande, uma panela de cerâmica nova e vários colares de concha.

Os Kamaiurá vivem num campo de atuação política relativamente circunscrito. No plano externo, o esforço maior é concentrado na manutenção da boa vizinhança e se possível no estabelecimento de alianças matrimoniais. Internamente é que se desenvolve uma disputa acirrada pelo poder, embora dissimulada por uma etiqueta que interpõe um afastamento protetor entre rivais. Nesse sentido, a maior parte dos planos e debates políticos se faz nos bastidores longe dos adversários, mesmo porque os que postulam posição de maior prestígio precisam preservar a imagem de apaziguadores e generosos.

As disputas políticas pelos postos de maior prestígio alimentam um fluxo constante de intrigas. A expressão "falar bobagem" indica uma falha de caráter própria dos opositores e significa levantar suspeitas infundadas, ameaçar 
veladamente alguém, criar clima de animosidade repetindo, em lugares impróprios, confidência de outros. A acusação de maior gravidade diz respeito à feitiçaria que é tanto um eficaz instrumento de ação política como uma tentativa de controlar a proliferação de poderes anti-sociais, originados nessa esfera cultural pouco estruturada que é a feitiçaria.

Assim que ocorrem acidentes, doenças, azares continuados e principalmente mortes inexplicáveis, inicia-se uma onda de comentários, aparentemente anônimos, mas que conduzem as suspeitas de feitiçaria em direção ao inimigo. A rede de intrigas que envolve a aldeia cria desconfianças e, no limite, acusações que atingem líderes de facções rivais, com o objetivo de minar pretensões políticas ou enfraquecer seu poder. Essa explicitação contundente do jogo pelo poder é mais difícil de negar do que provar, pois os Kamaiurá contam com recursos mágicos para identificar o agressor.

Quando ocorre uma morte súbita, o pajé é convocado para determinar sua origem. O procedimento usual é cortar um pouco do cabelo do morto e um pedaço pequeno de carne do dedo, que amarrados são levados para junto de um formigueiro de tocandira. Depois de cutucar o buraco das formigas, presta-se atenção em quantas delas picam o cabelo. Se elas passarem indiferentes a eles, exclui-se a possibilidade de feitiço. Mas se morderem a pequena trouxa, conta-se quantas o fizeram, definindo assim o número de pessoas envolvidas na feitiçaria. Sabendo-se o número de envolvidos, vai-se ao feiticeiro levando o pagamento (geralmente quatro colares) e a trouxinha. Lá chegando, e antes de propor o serviço, cliente e feiticeiro choram a morte da pessoa. Em seguida o oficiante pega o pagamento e o cabelo, prepara e bebe uma mistura de pimenta socada em água. Tira então lascas do feitiço (moã) e põe-se a espetar uma bonequinha feita com o cabelo do morto: primeiro finca as farpas debaixo de cada braço, depois na barriga e no topo da cabeça, repetindo a operação várias vezes. Adiciona um pouco de resina na bonequinha, amarra-a a um cipó (xiqui) e começa a girá-la, como se fosse um zunidor, ao mesmo tempo em que exclama: aká, aká, aká...A bonequinha se solta e vai longe, na direção da casa do assassino. Se ele for de outra aldeia, a bonequinha cai mais longe, no rumo da aldeia. De volta à casa, o cliente cozinha o cabelo numa panela com água e cipó timbó. Assim que começa a ferver, a água espirra confirmando a direção da casa de cada um dos envolvidos no crime. Isso é eficaz, dizem, "porque cabelo é como gente, mostra”. Depois de cinco ou seis dias de fervura, os culpados começam a morrer. Para interromper o processo, é só tirar o cabelo da mistura, queimar e enterrar. Alguns oficiantes colocam ainda junto à bonequinha de cabelo pimenta e osso de ariranha. Nesse caso, o culpado começa a comer apenas peixe cru, como as ariranhas, até que seu corpo todo começa a rachar e ele morre. O que confirma a previsão: "um feiticeiro está morrendo", dizem na aldeia. Quando nada disso funciona, o suspeito é morto a flechadas, pauladas, pelos homens que se disponham a executar a tarefa. 
A guerra de poderes não cessa, podendo ocasionalmente perder vigor por força da ameaça de um perigo maior externo. Mas tão logo a vida na aldeia retome seu curso normal, recomeça a batalha travada fora do controle social, isto é, nos limites externos da sociedade, espaço perigoso, mas também fonte de poder. O pajé que protege a sociedade das ações do feiticeiro adquire seu poder naquilo que Douglas (1976) denomina regiões desordenadas da mente, isto é no sonho e no transe. Mas somente um feiticeiro aliado, com seu poder antisocial e marginal, pode ajudá-lo a afastar a desordem e o infortúnio da aldeia.

Diversas vezes eu mesma me perguntei se é real a existência do feiticeiro ou se estamos apenas presenciando crises de disputa política acirrada numa sociedade que não conta com uma área bem articulada que torne legítimo e explícito o duelo de palavras entre opositores. Na falta desse espaço, a morte, que é a maior violência que o ser humano pode experimentar, instaura ela mesma uma escalada interminável de violência (Girard, 1990).

Surpreendentemente, tudo isso ocorre por detrás de relações afáveis e cordiais que os membros da comunidade mantêm e a tradição recomenda.

\section{Bibliografia}

DOUGLAS, M. Pureza e perigo. São Paulo, Perspectiva, 1976.

GIRARD, R. A violência e o sagrado. São Paulo, Universidade Estadual Paulista, 1990.

JUNQUEIRA, C. Os indios de Ipavu. 3a ed., São Paulo, Ática, 1979.

Junqueira C. "Símbolos e imagens da ordem na comunidade indígena". Em PASSETTI. E. e DIAS DA SILVA, R. B. (orgs.). Conversações abolicionistas: uma critica do sistema penal e da sociedade punitiva. São Paulo, IBCrim, 1997, pp. 21-47.

SAMAIN, E. Moroneta Kamayurá; mitos e aspectos da realidade social dos indios Kamaiurá (Alto Xingu). Rio de Janeiro, Lidador, 1991.

VILLAS BÔAS, O. e VILLAS BÔAS, C. Xingu. Os índios, seus mitos. Rio de Janeiro, Zahar, 1970.

RESUMO - o TEXTO estuda a relação entre pajelança e feitiçaria, atividades sociais que se opõem na cultura Kamaiurá. São examinados os procedimentos que acompanham doença e morte, ambos fatores de desordem no cotidiano da aldeia.

ABSTRACT - THIS TEXT studies the relationship between pajelança [shamanism] and feitiçaria [witchcraft], opposing social activities in the Kamaiurá culture. Procedures attending disease and death are examined, both seen as factors of disorder in the day-to-day life of the village.

Carmen Junqueira é antropóloga, formada em 1959 pela Escola de Sociologia e Política de São Paulo. É professora emérita da PUC de São Paulo. Escreveu diversos livros, como Os indios de Itapu (Ática), Antropologia indigena (Educ), Indigenismo na América Latina (Cortez) e Sexo e desigualdade (Rosa dos Tempos).

Texto recebido e aceito para publicação em 22 de setembro de 2004. 